Piotr KRAJEWSKI

UWM w Olsztynie

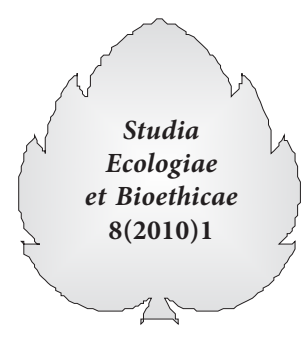

\title{
Starość w starzejącej się Europie
}

Wraz z upływającym czasem zmieniają się ludzie i rzeczywistość wokół nich. Najdotkliwiej skutki tych przemian odczuwają zazwyczaj ludzie starzy. Należą do tych grup społecznych, które z przyczyn społeczno-kulturalnych, polityczno-ekonomicznych, ale i czysto fizycznych, nie zawsze są w stanie dotrzymać kroku zapatrzonemu w przyszłość społeczeństwu1.

Do najtrudniejszych momentów ich egzystencji z pewnością należy okres wakacyjny. Dzieci i młodzież z utęsknieniem oczekują zakończenia zajęć lekcyjnych, aby móc w końcu poświęcić cały swój czas wypoczynkowi i ulubionym rozrywkom. Również pracujący zawodowo z przyjemnością myślą o urlopie, planując przyszły wypoczynek i sposoby uwolnienia się od stresu, towarzyszącego pracy zawodowej. Lato kojarzy się zwykle z najpiękniejszymi wyobrażeniami słońca, morza, gór i relaksującymi krajobrazami. Ponownie nawiązuje się przerwaną więź z przyrodą i odkrywa radość obcowania z najbliższymi nam osobami. W okresie wakacyjnym znacznie łatwiej jest nam zajrzeć w głąb siebie i poznać zagubioną gdzieś w codziennej krzątaninie własną osobowość.

Niestety, ta najprzyjemniejsza pora roku, dla wielu ludzi starych, pozostawionych we własnych mieszkaniach, szpitalach lub domach opieki społecznej nie zawsze kojarzy się z równie miłymi doznaniami. Problem nie należy do prostych i odnosi się do trudnego tematu odpowiedzialności; począwszy od odpowiedzialności urzędów i urzędników samorządowych, niezdolnych na czas i we właściwym zakresie zadbać o środki i opiekę instytucjonalną, kończąc na odpowiedzialności bezpośrednio zainteresowanych - ludzi w podeszłym wieku, ponieważ ważną, ale też i trudną rzeczą jest zaakceptowanie nowej roli społecznej i (często nie do pozazdroszczenia) sytuacji egzystencjalnej.

Przechodząc w stan spoczynku muszą znaleźć sobie nowe zajęcia i odmiennie organizować czas, jeśli nadal chcą aktywnie uczestniczyć w życiu społeczności i wciąż czuć się potrzebnymi, bo przecież bliscy i sąsiedzi tak jak dawniej wciąż na nich liczą, organizacje seniorów oczekują żywego zaangażowania, a naj-

1 Pontificium Consilium pro Laicis, La dignità dell'anziano e la missione nella Chiesa e nel mondo, Città del Vaticano 1998, s. 27. 
bliższa im parafia nie tylko wsparcia materialnego, ale też dobrego, przyjaznego słowa, uprzejmości i solidarności.

Kościół, stowarzyszenia społeczne i różnego rodzaju instytucje organizują wyjazdy i spotkania, które są okazją do zawierania nowych i zacieśniania starych przyjaźni, socjalizują i integrują z resztą społeczeństwa. Aktywne, ale nawet i bierne uczestnictwo w tych inicjatywach pomaga walczyć z monotonią codzienności i niebezpieczeństwami samotnego życia.

Z początkiem każdych wakacji dzienniki i serwisy informacyjne, często przesadnie dramatyzując powracają do problemów związanych z osobami starymi. Mówi się o trudnościach organizacyjnych instytucji, których zadaniem jest zapewnienie godnego życia, opieki socjalnej i zdrowotnej najbardziej potrzebującym; krótko mówiąc, godnej starości tym wszystkim, którzy nie są w stanie w pełni zadbać o nią we własnym zakresie i o własnych siłach. Poszukuje się możliwości rozwiązania, bardziej lub mniej wszystkich krępującego problemu, podsuwając różne pomysły, łącznie z propozycjami „adopcji rodzinnych” na czas określony. Dla wielu szpitali nie jest tajemnicą, że pewną część łóżek zajmują osoby, które - nie znajdując dla siebie innego rozwiązania - udają się do placówek opieki medycznej i społecznej, aby tam oczekiwać spotkania ze śmiercią w otoczeniu innych, niestety często tak samo zdesperowanych osób. W ten niecodzienny sposób chcą sobie zapewnić minimum zainteresowania własną osobą ze strony drugiego człowieka. To zjawisko tzw. „świątecznej lub wakacyjnej babci" w szpitalach, przytułkach i domach opieki znane jest w Europie od dawna i nie znika, a wręcz nasila się. W związku z tym oczekuje się, że organizacje, związki zawodowe i rządy państw zintensyfikują swe działania w prowadzeniu kompleksowej polityki socjalnej w tym zakresie, skłaniając się bardziej ku prewencji², a nie improwizowanych rozwiązań dla nagłych przypadków.

Można tylko dziękować za akty solidarności i zrozumienia ze strony ludzi wrażliwych i wolontariuszy, którzy w odpowiedzi na apele instytucji i organizacji niosą różnorodną pomoc ludziom starym i niedołężnym, którzy nie radzą już sobie z kłopotami dnia codziennego. Odpowiedzialna postawa ofiarnych obywateli nie może jednak zastąpić braków instytucjonalnych. Bez kompleksowych i globalnych rozwiązań społecznych osoby zaawansowane wiekowo z pewnością czują się bardziej „przedmiotami” powierzonymi opiece, aniżeli jej podmiotami. Logika akcyjności w nagłej potrzebie musi być zastąpiona poważną dalekowzroczną polityką ochrony społecznej, nastawionej na zagwarantowanie staremu człowiekowi niezbędnego minimum fachowej opieki medycznej i pogody ducha. Nieadekwatność struktur państwowych, samorządów lokalnych i instytucjonalnych przejawia się właśnie $\mathrm{w}$ ignorowaniu osób $\mathrm{w}$ wieku poprodukcyjnym. Jak dotąd nie zauważono, że szczęśliwy i zdrowy staruszek może być „inwestycją

E. Sgreccia, Manuale di bioetica, t. II, Milano 1996, s. 467-469. 
ekonomiczną". Z pewnością jest nią osoba otwarta, gotowa aktywnie zaangażować się na rzecz drugiego człowieka i społeczności. Opuszczony i nieszczęśliwy człowiek zamyka się w sobie, a to prowadzi do nagminnego dziś zjawiska samowykluczenia. Kończy zazwyczaj na szpitalnym łóżku bardziej wyniszczany pesymizmem życiowym niż chorobami. Wówczas rzeczywiście może stać się ciężarem dla siebie i dla innych. Inwestowanie w starość jest więc gwarancją radości życia całego społeczeństwa, poczynając od najmłodszych a kończąc na najstarszych.

Nic więc dziwnego, że dla wielu wiekowych obywateli naszego kontynentu letnia pora roku nie należy do tych najbardziej oczekiwanych. Wtedy, chyba bardziej niż kiedykolwiek odczuwają samotnośćs; wzmaga się poczucie niezadowolenia i depresja. Przypisują sobie status pokrzywdzonego przez społeczeństwo (które skąpi im niezbędnych do godnego życia świadczeń) i przez rodzinę, która często pozostawia ich samych sobie, wyjeżdżając na długo oczekiwane wakacje. Tych, którzy towarzyszą dzieciom i wnukom lub samodzielnie jadą na wypoczynek, jest naprawdę niewielu. Większość pozostaje w swoim miejscu zamieszkania.

Pozostawieni sami sobie i wyobcowani, w anonimowym środowisku, żyją w strachu. Boją się wszystkich i wszystkiego, każdej zmiany, nowej twarzy, nieprzewidzianej sytuacji. Wychodząc na zakupy trzymają się z dala od „rozbrykanych” i głośnych grup młodzieży, ruchliwych ulic i cichych zaułków. Przeświadczeni o swej bezbronności, jak oka w głowie strzegą skromnych emerytur i resztek dobytku. Nauczeni przykrymi doświadczeniami lub sugestywnymi informacji środków masowego przekazu, ograniczonym zaufaniem darzą tylko dawnych przyjaciół i sąsiadów, z niechęcią odnosząc się do obcych.

Rozlicznych problemów ludzi przykutych do łóżka lub wózka inwalidzkiego nie można rozwiązać okresowymi akcjami dostarczania podstawowych produktów spożywczych i niezbędnych leków do domu. Demonstrowany przy okazji triumfalizm sprawności instytucji organizujących akcje wydaje się nieco przesadzony. Okazjonalna pomoc i lekarstwa poprawiające dolegliwości fizyczne są niezmiernie ważne, ale z pewnością nie usuną dyskomfortu psychicznego, który jest dużo bardziej skomplikowany i wymaga rozwiązań kompleksowych, wynikających z szerokiej polityki rodzinnej i społecznej, opartej na autentycznej solidarności międzyludzkiej i międzypokoleniowej, obejmującej jednocześnie aspekty fizyczne i psychiczne, ekonomiczne i moralne, społeczne i kulturalne.

Człowiekowi staremu należy pomóc przezwyciężyć jego własną izolację, aby ponownie poczuł się potrzebny we współtworzonej rzeczywistości bogatej w dostępne świadczenia i możliwości ułatwiające autentyczne i swobodne wyrażanie własnej osobowości.

Osoba stara nie może żyć w samotności oczekując, aż ktoś odbierze telefoniczne wezwanie pomocy i postara się zaspokoić jej potrzeby. Musi mieć zapew-

3 Pontificium Consilium pro Laicis, $d z$. cyt., s. 9. 
niony nieustanny kontakt z innymi ludźmi. Oczywiście, każdy czasami potrzebuje chwili samotności i wypoczynku w otoczeniu własnych mebli, drobiazgów i wspomnień, ale potem zawsze wraca potrzeba towarzystwa, dyskusji, spacerów czy pójścia do kościoła. ${ }^{4}$ Okazjonalna pomoc domowa najbliższych lub obcych rozwiązuje okresowe potrzeby, ale nie stanowi optymalnego rozwiązania problemu wciąż rosnącej liczby ludzi starych.

$\mathrm{O}$ alarmującym procesie starzenia się społeczeństwa ${ }^{5}$ państw Europy wciąż donoszą badania demograficzne i socjologiczne. Nie jest to problem możliwy do rozwiązania wyłącznie na drodze politycznej. W pierwszym rzędzie oczekuje się dalekowzrocznych działań wspomagających nade wszystko rodzinę, dopiero potem instytucji i organizacji non profit, które inspirowane poczuciem potrzeby niesienia pomocy drugiemu człowiekowi, wprowadzą w życie skuteczne programy, wsparte autentyczną miłością, a przede wszystkim odpowiedzialnością.

To, że ktoś wchodzi w wiek starczy nie oznacza, iż wyzbywa się wszelkich zobowiązań wobec innych obywateli i społeczności. Dzisiejsza skomplikowana sytuacja jest pochodną decyzji politycznych, społecznych, ekonomicznych i kulturowych podjętych w przeszłości. Stąd dyspozycyjność i angażowanie się w działalność na rzecz społeczeństwa jest podstawowym obowiązkiem każdego człowieka w podeszłym wieku w celu zagwarantowania sobie i innym możliwie godnej przyszłości. Ludzie starzy są „powiernikami przeszłości” i będą nimi w takiej mierze, w jakiej zakorzeniona w nas świadomość stanie się obowiązującym dla wszystkich stylem życia, nastawionym na tworzenie warunków, gwarantujących pełne zaspokojenie ich osobistych i środowiskowych wymogów. Nowa rzeczywistość demograficzna, tak charakterystyczna dla społeczeństw uprzemysłowionej Europy w niewielkim stopniu oddziałuje na podejmowanie decyzji politycznych, wciąż ignorując dokonujące się w międzyczasie zmiany. Aby nie zaprzepaścić szans należy stworzyć takie warunki, aby również ludzie starzy mieli wpływ na rozwiązywanie problemów systemu opieki zdrowotnej, rozwoju gospodarczego, szkolnictwa i kultury; są jedyną grupą społeczną, która ma potrzebę i jest w stanie zaoferować swój jakże cenny wkład w życie społeczne w postaci doświadczenia. Korzystając $\mathrm{z}$ tej oferty społeczeństwo uwrażliwi się na problemy godnego życia, które musi być zagwarantowane wszystkim obywatelom stosownie do wymagań wieku.

Rozwijanie relacji z młodym pokoleniem musi wynikać z poczucia solidarności, potrzeby wymiany doświadczeń i utrzymania kontaktów interpersonalnych (przede wszystkim w obrębie rodziny). W ten sposób młodzi nie zostaną

Pontificium Consilium pro Laicis, $d z$. cyt., s. 31-37.

5 Na temat demografii i problemu starzenia się populacji, interesujące wydają się sugestie zawarte w: Pontificio Consiglio per la Famiglia, Evoluzioni demografiche. Dimensioni etiche e pastorali, „Medicina e Morale” 3(1994), s. 527-559. 
pozbawieni roztropnego przewodnictwa dziadków, a seniorzy będą mieli zapewnioną możliwość poznawania na bieżąco realiów współczesności. Wzajemne zrozumienie wynikające $z$ właściwych relacji międzypokoleniowych, nie będzie kończyło się autoizolacją i automarginalizacją ludzi starych ${ }^{6}$, a i młodzi nie będą widzieli potrzeby, aby im w tym „pomagać”. Osoby zaawansowane wiekowo nie będą ograniczały się jedynie do spotkań w swoim kręgu, ale jako dojrzali politycznie i społecznie obywatele staną się siłą, której głos będzie się liczył w podejmowaniu najważniejszych decyzji państwowych.

$\mathrm{W}$ obecnych czasach $\mathrm{z}$ niepokojem przyglądamy się, jak kultura narodów żyjących chwilą teraźniejszą wyjaławia się i zanika, ponieważ powoli traci więź z członkami rodziny i korzeniami własnej historii. I tu również nieocenionej pomocy są w stanie dostarczyć ludzie starzy, którzy mogą i powinni być powiernikami tradycji, aby zwyczaje, obrzędy, rocznice, sztuki piękne i kultura muzyczna czy rzemiosło nie zostały zapomniane przez młode pokolenia. To wszystko, co mogą uratować z przeszłości, powinno stanowić integralną część tożsamości narodowej oprócz satysfakcjonującego i oryginalnego życia osobistego i społecznego.

Tego wszystkiego można dokonać, odbudowując więzi rodzinne, organizując wolontariat indywidualny i instytucjonalny. $\mathrm{W}$ zamian za to ludzie starzy pomogą docenić tradycję i odkryć inny sposób pełnego korzystania z życia, który stanie się alternatywą dla płytkiego konsumizmu niszczącego tożsamość indywidualną, rodzinną i społeczną.

\section{Podsumowanie}

O procesie starzenia się społeczeństw Europy donoszą badania demograficzne i socjologiczne. Problemu tego nie można rozwiązać na drodze politycznej. Oczekuje się dalekowzrocznych działań wspomagających nade wszystko rodzinę. To, że ktoś wchodzi w wiek starczy nie oznacza, iż wyzbywa się wszelkich zobowiązań wobec innych obywateli i społeczności. Dzisiejsza skomplikowana sytuacja jest pochodną decyzji politycznych, społecznych, ekonomicznych i kulturowych podjętych w przeszłości.

Rozwijanie relacji z młodym pokoleniem musi wynikać z poczucia solidarności, potrzeby wymiany doświadczeń i utrzymania kontaktów interpersonalnych, przede wszystkim w obrębie rodziny. W ten sposób młodzi mogą cieszyć się roztropnym przewodnictwem dziadków, a seniorzy mają zapewnioną możliwość poznawania na bieżąco realiów współczesności. Wzajemne zrozumienie wynikające $\mathrm{z}$ właściwych relacji międzypokoleniowych, nie będzie kończyło się

\footnotetext{
${ }^{6}$ J. ZIELIŃsKi, Zachwianie pozycji osób starszych $w$ rodzinie i społeczeństwie w dobie globalizacji i przemian cywilizacyjnych, materiały niepublikowane ze spotkania „Dnie rodziny” Kętrzyn, 04.06.2009; E. SGRECCIA, dz. cyt., s. 452.
} 
autoizolacją i automarginalizacją ludzi starych, a i młodzi nie będą widzieli potrzeby, aby im w tym „pomagać. W obecnych czasach z niepokojem przyglądamy się, jak kultura narodów żyjących chwilą teraźniejszą wyjaławia się i zanika, ponieważ powoli traci więź z członkami rodziny i korzeniami własnej historii. Nieocenionej pomocy mogą dostarczyć ludzie starzy, którzy mogą i powinni być powiernikami tradycji, aby zwyczaje, obrzędy, rocznice, religia, sztuka i kultura muzyczna czy rzemiosło nie zostały zapomniane przez młode pokolenia. To wszystko, co mogą uratować z przeszłości, powinno stanowić integralną część tożsamości narodowej oprócz satysfakcjonującego i oryginalnego życia osobistego i społecznego.

Tego wszystkiego można dokonać, odbudowując więzi rodzinne, organizując wolontariat indywidualny i instytucjonalny. $\mathrm{W}$ zamian za to ludzie starzy pomogą nam docenić tradycję i odkryć inny sposób pełnego korzystania z życia, który stanie się alternatywą dla płytkiego konsumizmu niszczącego tożsamość indywidualną, rodzinną i społeczną.

\section{Old age in the aging Europe}

\section{SUMMARY}

The development of relationships between young people and the generation of the grandparents must be accompanied by a sense of solidarity and the need to share experiences especially in the family circle. In this way young people are slowly gaining experience in finding thread of understanding and creating relations with other people from atomising population. Mutual understanding and keeping good relations between the generations also prevents the isolation and marginalization of the older generation; then the young people do not see any interest to "help" them in this.

Today we can observe with concern how culture of the nations living with the present moment is getting exhausted and disappears, because the individual gradually is losing its connection with family members and the roots of its own history. After all, the older people are able to offer invaluable assistance to young people, they can be and should be the trustees of the past and all these things in order to prevent young generation from forgetting traditions, customs, art, religion, music, culture and crafts of their fathers. 